\title{
Geographic structure and regional socio- economic impact of low-cost airlines in selected cities of Central and Eastern Europe: the role model for Belarus.
}

\author{
Andrei Bezruchonak ${ }^{1, *}$ \\ ${ }^{1}$ BELARUSIAN STATE UNIVERSITY, Department of Geography, 220030, Leningradskaya st. 16- \\ 216, Minsk, Belarus
}

\begin{abstract}
The goal of this article is to analyse the structure of geographic presence and the socio-economic impact of low-cost carriers (LCCs) in the selected countries of Central and Eastern Europe (neighbouring the Republic of Belarus - Poland, Lithuania, Latvia, Ukraine and Russia). The model of the current geographic configuration of the LCCs network from the cities and airports with the closest proximity to Belarus was designed. The current market trends show that the major LCCs on the market are Wizz Air and Ryanair, and they are increasing their share at the markets of the countries analysed (particularly after Ryanair entered Ukrainian market in 2018). The overview of socio-economic impact of LCCs is discussed with accent on the possible benefits and outcomes of LCCs entry to the Republic of Belarus.
\end{abstract}

\section{Introduction}

In chronologic and geographic dimensions, the origin of the term "low-cost carrier" (LCC) dates back to the late 1940s, tracing to the US, where the Pacific Southwest Airlines had pioneered the concept by starting operations from San Diego, CA. The Southwest Airlines had successfully developed the LCCs business model in its contemporary form after the Airline Deregulation Act of 1978.

Some core features that contributed to the success of the original LCCs business model included: high aircraft utilisation; use of secondary airports; minimum cabin crew; lower wage scales; lower rates of unionisation; one class of seating; short turn-around times; simple fare structures and price strategies; adoption of strict yield management techniques; no frills; no connections; point-to-point services [1]. By practising cost leadership via significant cost cutting and improving efficiency of the overall business process, LCCs could sell tickets at prices lower than traditional carriers (up to $53 \%$ lower) $[1,2,3]$.

In the European Union, the airline market environment had changed significantly in the 1990s, after the three deregulation and liberalization "packages" were adopted in 1987 (abolishing bilateral capacity sharing between countries), 1990 (removing price controls as

* Corresponding author: Bezruchonak@bsu.by 
well as capacity and market access restrictions) and 1993 (completing deregulation process and creating the common market) accordingly. That led to the change of the market environment, where the new market entrants (LCCs) started challenging the traditional bilateral model of charter and traditional scheduled airlines.

The European LCCs originated in Ireland in the late 1980s, where Ryanair (the future CEO of the company, Michael O'Leary had an internship at the Southwest Airlines) copied and incorporated the low cost business model on flights from Dublin to London. In 1995, easyJet had started operations from London Luton. The patterns of the further geographic expansion of LCCs in Europe can be structured into the following four stages:

1) Expansion to continental part of Western Europe (1992-1996); 2) Expansion to the tourist destinations of Southern Europe (1997-2003); 3) Expansion to the newly accepted EU countries of Central and Eastern Europe (i.e. Ryanair, Wizz Air and easyJet routes from regional Polish airports to the UK and Ireland; 2004-2012); 4) Expansion across the Atlantic Ocean and to non-EU CEE and Asian countries (i.e. Norwegian, WOW and Level long-haul flights to the US, Wizz Air flights to Ukraine, Georgia, Russia and Kazakhstan; 2012-onwards) [1, 3, 4, 5].

With the entry of new LCCs into the market, competition increased and prices decreased, especially on the most busy routes (i.e. from $£ 199$ to $£ 9.99$ between London and Dublin), while new destinations, routes, airports and airlines became accessible and affordable [5, 6]. Since the early 2000s, the entry and rapid growth of LCCs has redistributed market shares among the major airline market players. In particular, LCCs increased their market share from 5\% in 1998 to $30 \%$ in 2008 , while the market share of legacy carriers declined from $78 \%$ to $60 \%$ over the same decade (to $53 \%$ in 2016). Almost non-existent before 1995, by 2012 the low-cost sector had left the network carriers' sector behind ( $44.8 \%$ vs $42.4 \%$ ) and by 2015 represented $48 \%$ of intra-European capacity $[5,7]$.

It is worth noticing that in a dynamic and competitive market environment, the original LCCs model is currently experiencing changes, modifications and adaptations, such as: 1) unionizing (i.e. the case of Ryanair accepting pilot unions in 2018); 2) launching long-haul flights in addition to traditional short-haul networks (i.e. LEVEL (IAG Group) launching flights from Barcelona to the Americas in 2017); 3) introducing differentiated seats allocation and loyalty programs (i.e. Wizz Discount Club, etc.); 4) shifting towards central airports (i.e. to Barcelona El Prat instead Reus and Girona or to Frankfurt International instead of Hahn); 5) offering connecting flights and feeding partnerships with traditional carriers (i.e. Ryanair offering bookings of long-haul flights operated by Air Europe or Aer Lingus networks) on long-haul destinations [3, 4, 5].

\subsection{Literature review}

The analysis of the existing literature on LCCs had shown the major directions in the field that had influenced the general research methodology of this paper. Numerous works provide general overview of LCC origin, business models and expansion trends ( $\mathrm{R}$. Doganis, P. Trszepacz, S. Gross, A. Schröder, E. Pijet-Migoń, et.al), as well as their impact on migration, tourism and socio-economic development on regional communities and cities (M. Akgüç, F. Dobruszkes, A. Debuser, E. Pancer-Cybulska, E. Szostak, et.al). In general, it is worth noticing that currently there are few academic works in human geography explaining the socio-economic impact of the LCCs in CEE, and almost no research on the impact of neighbouring airports (absorbing potential passengers from Belarus - the only country in the region with no LCCs) and potential effect of LCCs presence on Belarus in particular. 


\subsection{Methodology}

Statistical and analytical data on the current state of LCCs in the EU and CEE discussed in the article is based on content analysis of open access publications and reports, provided by the following international agencies and institutions: European Parliament, World Bank, Eurostat, official data of OAG, Centre for European Policy Studies (CEPS), PwC, etc. Other relevant publications, industry reports and policy papers were analysed in order to provide the reader with better understanding of the emerging phenomenon of LCCs growth and impact in Eastern Europe.

The connectivity analysis of the nearest airports was based on the quantitative analysis of the direct flights route network of the major 6 European LCCs operated from the airports with the closest proximity to Belarus (see table 1). The information about current route network (313 routes in total) from 11 selected cities (Warszawa, Olstyn, Lublin, Rzeszow, Vilnius, Kaunas, Palanga, Riga, Kyiv, Lviv, Moscow) was obtained from the official web pages of the following LCCs: Ryanair, Wizz Air, EasyJet, Norwegian, Vueling and Pegasus. The main criteria of the airports selection (13 in total) was their proximity to Minsk (as the capital city) and to regional centres of the republic of Belarus (Hrodna, Brest, Homiel, Mahilieu and Viciebsk).

Table 1. Direct routes of LCCs from the selected CEE cities. Source: [8, 18-23]

\begin{tabular}{|c|c|c|c|c|c|c|c|c|c|}
\hline City & $\begin{array}{c}\text { Airport } \\
\text { code }\end{array}$ & $\begin{array}{c}\text { Entrance } \\
\text { of LCCs }\end{array}$ & RYR & EZY & NAX & VLG & WZZ & PGT & TOTAL \\
\hline Warszawa & WAW & 2004 & 1 & 4 & 3 & 1 & 50 & 0 & 59 \\
\hline Warszawa & WMI & 2012 & 55 & 0 & 0 & 0 & 0 & 0 & 55 \\
\hline Vilnius & VNO & 2004 & 24 & 0 & 2 & 0 & 26 & 0 & 52 \\
\hline Riga & RIX & 2004 & 19 & 0 & 4 & 0 & 13 & 0 & 36 \\
\hline Kyiv & KBP & 2008 & 12 & 0 & 0 & 0 & 0 & 1 & 13 \\
\hline Kyiv & IEV & 2011 & 0 & 0 & 0 & 1 & 26 & 0 & 27 \\
\hline Moscow & MOW* & 2006 & 0 & 0 & 0 & 1 & 2 & 1 & 4 \\
\hline Kaunas & KUN & 2004 & 19 & 0 & 0 & 0 & 7 & 0 & 26 \\
\hline Palanga & PLQ & 2015 & 2 & 0 & 1 & 0 & 1 & 0 & 4 \\
\hline Lublin & LUZ & 2012 & 2 & 0 & 0 & 0 & 6 & 0 & 8 \\
\hline $\begin{array}{c}\text { Olstyn } \\
\text { Mazury }\end{array}$ & SZU & 2016 & 1 & 0 & 0 & 0 & 2 & 0 & 3 \\
\hline Rzeszow & RZE & 2005 & 10 & 0 & 0 & 0 & 0 & 0 & 10 \\
\hline Lviv & LWO & 2008 & 5 & 0 & 0 & 0 & 10 & 1 & 16 \\
\hline 11 Cities & $\mathbf{1 3}$ & & $\mathbf{1 5 0}$ & $\mathbf{4}$ & $\mathbf{1 0}$ & $\mathbf{3}$ & $\mathbf{1 4 3}$ & $\mathbf{3}$ & $\mathbf{3 1 3}$ \\
airports & & & & & & \\
\hline
\end{tabular}

Note: airlines ICAO codes - RYR (Ryanair), EZY (easyJet), NAX (Norwegian), VLG (Vueling), WZZ (Wizz Air), PGT (Pegasus)

The maps presented in this article were designed in ESRI ArcGIS software using standard geographic approach towards spatial data visualization. Measurement units of the indicators studied are provided in standard Metric System.

\section{Main findings}

According to ICAO data, there were 34 European LCCs operating in 2017 [9]. According to the estimations based on OAG schedules data, almost 502 million low-cost seats were supposed to be flown in Europe in 2018 (124\% growth since 2009). In 2017 LCCs accounted more than $36 \%$ of the market seats share (vs. $24 \%$ in 2009), and the forecast 
based on the average annual growth projects the 50\% share by 2027 [10]. Ryanair, EasyJet, Norwegian, Vueling and Wizz Air are the five largest carriers in Europe, by the numbers of passengers carried in 2017 (table 2).

Table 2. The largest low-cost carriers in Europe, 2017. Source: $[4,5,10]$

\begin{tabular}{|c|c|c|c|c|c|c|}
\hline Airline & Country & Launch & Routes & Countries & $\begin{array}{c}\text { Passengers, } \\
\text { mln. }\end{array}$ & Fleet \\
\hline Ryanair & Ireland & 1985 & 1800 & 37 & 120 & 400 \\
\hline easyJet & UK & 1995 & 682 & 36 & 80,8 & 279 \\
\hline Norwegian & Norway & 1993 & 500 & 35 & 33,2 & 144 \\
\hline Vueling & Spain & 2004 & 119 & 34 & 29,6 & 85 \\
\hline Wizz Air & Hungary & 2003 & 525 & 44 & 29,6 & 104 \\
\hline
\end{tabular}

In 2018, in terms of LCC seats capacity, the biggest market in Europe were Spain (82.2 million departing seats), with the UK second (75.21 million) and Germany third (55.68 million). The countries with the largest share of LCCs by international seat capacity were Poland (59\%), UK (57\%), Spain (56\%), Italy (55\%) and Ireland (52\%); by domestic seat capacity- UK (66\%), Spain (48\%) and Italy (47\%) [10].

Over the last decade, the market penetration of LCCs has increased significantly in the countries of Central and Eastern Europe. That was the result of the accession rounds to the European Union (in 2004 and 2007), resulting in more business and tourism trips between east and west with LCCs. Warszawa Chopin, Vilnius, Kaunas, Riga were among the first airports to welcome LCCs in 2004 (see table 2). When Poland joined the European Union in 2004, the seat capacity in international flights was 4.6 million, of which $9 \%$ came from LCCs (in 2017, the capacity offered by LCCs in international flights accounted for $59 \%$ of capacity). This suggests that the availability of LCCs has likely generated new travel demand in Europe $[5,8,10]$. However, only few internationally operating LCCs have their corporate headquarters within the CEE region (i.e. Wizz Air (Hungary), Blue Air (Romania), airBaltic (Latvia; changed its model from a point-to-point semi-LCC to hub and spoke hybrid carrier)).

In 2017-2018, almost all countries of the CEE region have had LCCs operating on regular basis at their markets of passenger air transportation. Belarus was the only country in Europe with the lowest market penetration for LCCs. The share of $0.7 \%$ (followed up by $6.4 \%$ of Russia) in 2018 was the result of Vueling's twice-weekly summer seasonal service from Barcelona to Minsk. Following Belarus and Russia, other post-Soviet states, such as Azerbaijan (10.8\%), Ukraine (11\%), Moldova (12.6\%) and Armenia (12.9\%) top the list of countries in Europe with the lowest LCCs market penetration [10, 23].

It is a documented fact, that Belarusians cross borders of Poland, Lithuania, Latvia and Ukraine to take low-cost flights from Vilnius, Kaunas, Warsaw, Lublin, Riga and Kiev. Belarus can be considered as a market with a significant demographic potential ( 9.5 million people with more than $70 \%$ of urban population), especially when comparing to Lithuania with a population of 2.8 million (LCCs have $57 \%$ of market share). Because of high airports connectivity to European air transportation market, marked by presence of such LCCs, as Ryanair and Wizz Air, Lithuania's airports processed just under 5.25 million passengers in 2017 (Minsk International Airport processed 4.11 million passengers, while Belarusian regional airports accounted for less than 100,000 passengers) [10].

The Hungarian airline Wizz Air is the market leader among LCCs in CEE, with a market share $42.3 \%$ of low-cost airline traffic in the region and $16.1 \%$ of the total CEE market (followed up by Ryanair with $29.8 \%$ and $11.3 \%$ respectively) [11]. The ranking of LCCs by market share in the EU countries, neighboring Belarus, is presented in table 3. 
Table 3. The LCCs ranking by low-cost and total market share in selected CEE countries - neighbors of the Republic of Belarus, 2017. Source: [11]

\begin{tabular}{|c|c|c|c|c|}
\hline Country & LCCs market & $\begin{array}{c}\text { Share, } \\
\mathbf{\%}\end{array}$ & Total market & $\begin{array}{c}\text { Share, } \\
\mathbf{\%}\end{array}$ \\
\hline \multirow{3}{*}{ Poland } & Ryanair & 50 & Ryanair & 26 \\
& Wizz Air & 42 & LOT & 25 \\
& Norwegian & 4 & Wizz Air & 22 \\
\hline \multirow{3}{*}{ Lithuania } & Ryanair & 51 & Ryanair & 30 \\
& Wizz Air & 45 & Wizz Air & 26 \\
& Norwegian & 4 & Air Baltic & 10 \\
\hline \multirow{3}{*}{ Latvia } & Ryanair & 52 & Air Baltic & 59 \\
& Wizz Air & 30 & Ryanair & 13 \\
& Norwegian & 17 & Wizz Air & 7 \\
\hline \multirow{3}{*}{ Ukraine } & Wizz Air & 57 & Ukraine Intl. & 37 \\
& Pegasus & 19 & Aeroflot & 10 \\
& Ernest & 12 & Wizz Air & 7 \\
\hline
\end{tabular}

As presented in the table above, the major LCC players, operating in the countries that have borders with Belarus, are Ryanair (leading positions at LCCs markets in Poland, Lithuania and Latvia) and Wizz Air (leading in Ukraine, but it is worth to notice that Ryanair entered the Ukrainian market (Kyiv and Lviv) in fall 2018).

The network analysis was carried out for 313 LCCs routes, operated by 6 airlines from 13 airports of 10 cities (see figure 1). The most connected airports (by number of LCCs routes) among the selected ones are Warszawa Chopin (19\% of all LCCs routes), Warszawa Modlin (18\%) and Vilnius (17\%). The least connected airports are Olstyn Mazury, Palanga (small regional airports) and Moscow (air transportation hub of all the airports, low numbers are explained by low market presence of European LCCs).

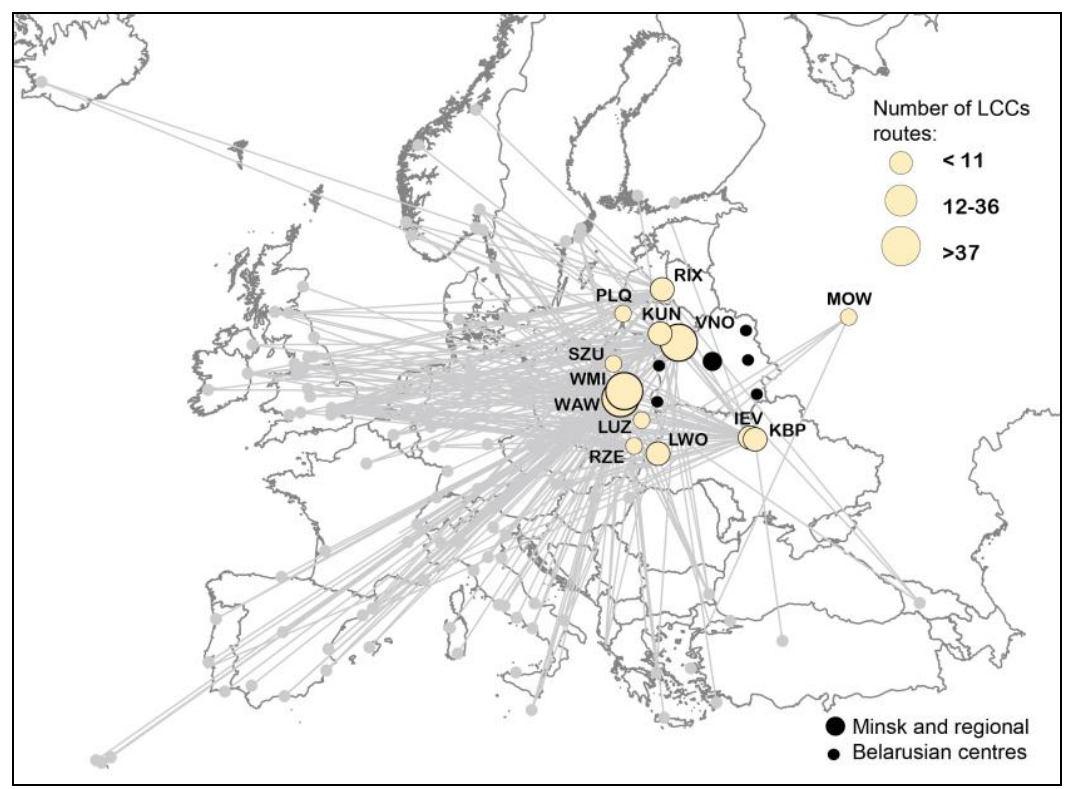

Note: excluding routes to Morocco, Cyprus, Israel and Jordan

Fig. 1. Network of the major low-cost carriers, operating from the airports with the closest proximity to Belarus. Source: [18-23] 
Ryanair (operates on $46 \%$ of all the routes from 11 cities) and Wizz Air (41\%) dominate within the routes network of LCCs operating from 11 cities that attract Belarusian travellers in terms of low-cost mobility. The gap between the market leaders and other LCCs is significant - the closest rival, Norwegian, accounts for $3 \%$, and easyJet - for $1 \%$ of all routes within the network (see figure 2).

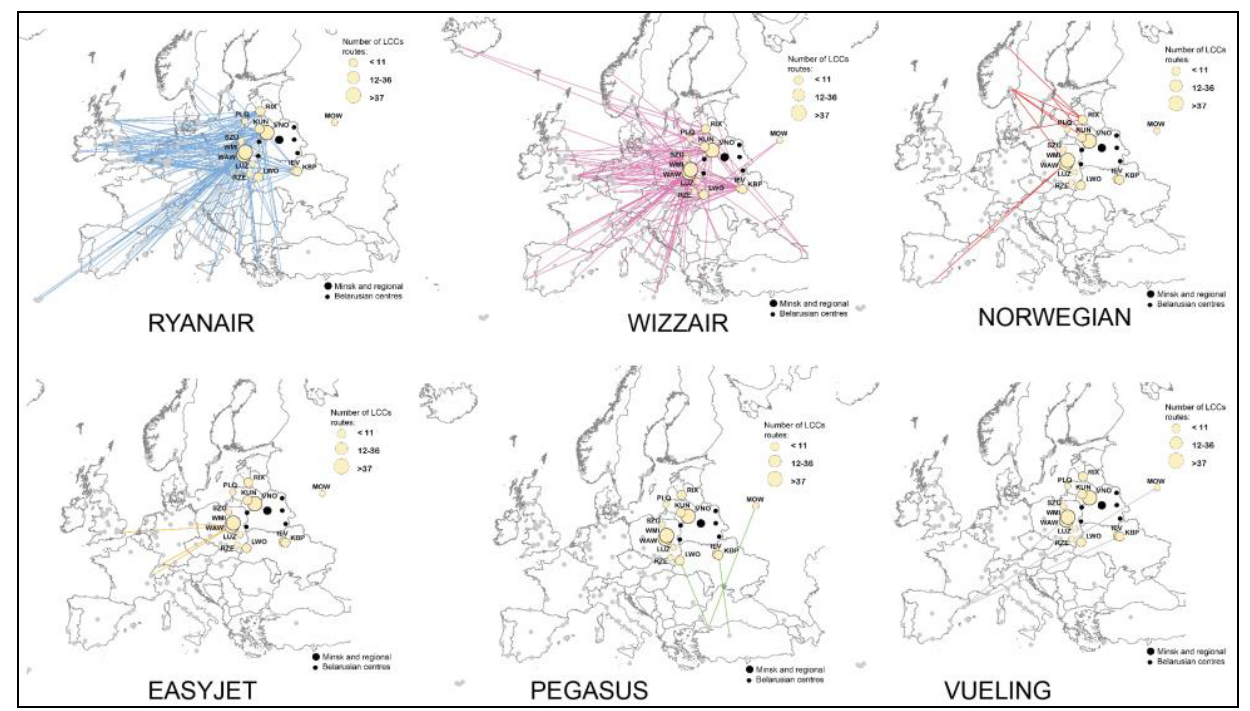

Note: excluding routes to Morocco, Cyprus, Israel and Jordan

Fig. 2. Route network of the major LCCs from selected cities, 2018. Source: [18-23]

The geographic analysis of the selected LCCs routes from the selected cities reveals that Poland is the most connected country among Belarusian neighbours $(43 \%$ of all routes originate there, see figure 3), followed up by Lithuania (26\%), Ukraine (18\%) and Latvia $(12 \%)$. That reflects the economic and regulative openness of the local market and defines the possible travel patterns of Belarusians when choosing the airport of departure.

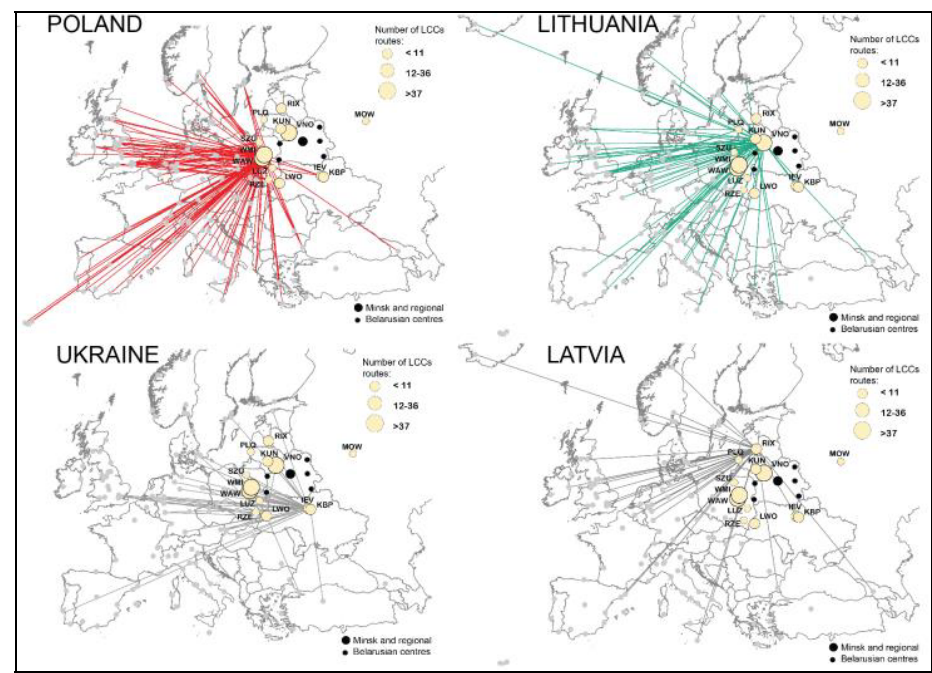

Note: excluding routes to Morocco, Republic of Cyprus, Israel and Jordan

Fig. 3. Route network of examined LCCs from the selected CEE countries, 2018. Source: [18-23] 


\section{Discussions and conclusions}

The dynamic impact on spatial socio-economic development and effects caused by LCCs presence is complex and interrelated with all sectors of society [12]. The general opinion is that entry of LCCs brought significant socio-economic benefits to the consumers, airports, cities and regions across European regions due to improved connectivity and therefore higher integration into the global air transportation network. Air connectivity is considered as a key to unlocking a region's or cities economic growth potential, in part because it enables the country to attract business investment and human capital. An increase in air connectivity also spurs tourism, which is vital to many countries' economic prosperity [13]. Thus, estimations in Latvia had shown that a $10 \%$ improvement in air connectivity relative to GDP would see an increase of EUR 11.5 million per annum in long-run GDP for the economy [14].

European budget airlines enabled people to travel at lower prices (promoting leisure, business, educational Erasmus mobility), created new on-site jobs and stimulated economic growth, connected European regions and made traditional carriers and airports to reduce their prices and to be more competitive and efficient $[5,15]$.

The dynamics of traffic growth at Polish regional airports from 2003 to 2010 had no precedence in the history of Polish aviation: the largest increases for the period were recorded in the following regional airports: Lodz (Lublinek) - 5814.3\%, Bydgoszcz 1230.0\%, Katowice (Pyrzowice) - 817.1\% and Gdansk (Rebiechowo) - 507.1\%, Rzeszow $-487.3 \%$. Renovation of regional airports infrastructure and the entry of LCCs, followed by growing number of flights from Polish regional airports helped regions to improve their transport accessibility and territorial cohesion, which can result in the future in the more dynamic socio-economic development $[15,16]$.

LCCs also contribute to the increase of regional employment and wealth (i.e. by 2018 Ryanair created 1500 on site jobs in Lithuania (60\% in Vilnius, $40 \%$ in Kaunas)) - i.e. one million of passenger traffic generated 286 on-site jobs.

LCCs enhanced the accessibility of major cities and secondary destinations, less discovered by tourists. For example, new routes offered by LCCs in the eastern European regions triggered more and more tourist travel to capitals such as Vilnius, Gdansk, Lviv, Krakow, Riga as well as other relatively smaller cities in the CEE region, which promote their cultural heritage to tourists from Western Europe [17]. The number of tourist arrivals to the CEE countries increased from 70 million in 2000 to 133 million in 2017 [5].

The conclusion is that the positive European experience of deregulation and liberalization (particularly, the one in the CEE countries) can be a good lesson to be learned by transportation authorities in Belarus, supporting the existing monopoly of the national carrier Belavia. The entry of LCCs can not only increase the numbers of tourist arrivals, but also contribute to the development of regional airports and cities (i.e. in Brest and Hrodna, which are visa-free to visit for the citizens of the EU).

However, it is worth to be careful with the characteristics of the complex impact of LCCs presence and to bear in mind the possible negative impact. New employment provided by regional airport may lead to job losses in other sectors (i.e. railway sector). Stimulated tourism to other countries may cause losses at the home country's tourism industry [12]. The proximity of LCCs regional airport in another country may lead to the passenger numbers losses (the case of Vilnius airport, absorbing passengers from Belarus).

\section{References}

1. EP, The Consequences of The Growing European Low-Cost Airline Sector, EP's Committee on Transport and Tourism, Brussels (2007). 
2. R. Doganis, The Airline business in the twenty-first century, Routledge (2001)

3. S. Gross, M. Luck, The Low Cost Carrier Worldwide, Routledge (2016)

4. C. Schlumberger, N. Weisskopf, Ready for Takeoff? The Potential for Low-Cost Carriers in Developing Countries. Directions in Development, World Bank (2014)

5. M. Akgüç, M. Beblavý, F. Simonelli, Low-Cost Airlines: Bringing the EU closer together, CEPS Research Report, CEPS (2018)

6. ELFAA, Liberalisation of European Air Transport: The Benefits of Low Fares Airlines to Consumers, Airports, Regions and the Environment, European Low Fares Airline Association report, Brussels (2004)

7. A. Debuser, Low-cost air carriers and tourism, European Parliament, EPRS (2017)

8. E. Pijet-Migoń, Zmiany rynku lotniczych przewozów pasażerskich w Polsce po akcesji do Unii Europejskiej, Rozprawy Naukowe Instytutu Geografii i Rozwoju Regionalnego Uniwersytetu Wrocławskiego, Wroclaw (2012)

9. ICAO, List of Low-Cost-Carriers (based on ICAO definiton), access mode: https://www.icao.int/sustainability/Documents/LCC-List.pdf (2017)

10. Anna.aero, based on OAG Schedules Analyser data, LCC capacity in Europe (2018) access mode : https://www.anna.aero/2018/07/18/lcc-capacity-in-europe-set-for-half-abillion-seats-in-2018/

11. Wizz Air Holdings Plc Annual report and accounts (2018)

12. S. Gross, A. Schröder, Handbook of Low Cost Airlines: Strategies, Business Processes and Market Environment, Erich Schmidt Verlag GmbH \& Co KG (2007)

13. PwC, Connectivity and growth. Are European airport valuations taking off? PwC (2017)

14. Economic Benefits from Air Transport in Latvia, Oxford Economics (2011)

15. E. Pancer-Cybulska, E. Szostak, Ł. Olipra, The impact of the migration processes on the low cost airlines' routes between EU countries and Poland after its accession to the EU, and on the territorial cohesion of Polish regions, University of Wroclaw (2011).

16. P. Trzepacz, Spatial Aspects of Air Transportation Liberalization - Changes In European Airport Hierarchy, Bulletin Of Geography (Socio-Economic Series) No. 8 (2007)

17. F. Dobruszkes, New Europe, new low-cost air services, Journal of Transport Geography, 17(6) (2009)

18. Wizzair. On-line available on: https://wizzair.com/en-gb/flights/map\#/

19. Ryanair. On-line available on: https://www.ryanair.com/pt/pt/destinos-voos-baratos

20. Flypgs. On-line available on: https://www.flypgs.com/en/useful-info/info-aboutflights/our-network

21. Easyjet. On-line available on: http://www.easyjet.com/EN/routemap

22. Norwegian. On-line available on: https://www.norwegian.com/en/route-map/

23. Vueling. On-line available on: https://www.vueling.com/en/book-your-flight/wherewe-fly 